\title{
THE ROLE OF INFORMATION AND COMMUNICATION TECHNOLOGY (ICT) TO ALLEVIATE POVERTY IN BANGLADESH
}

\author{
Md. Shahnur Azad Chowdhury \\ Associate Professor \\ Department of Business Administration \\ International Islamic University Chittagong, Bangladesh \\ E-mail: tipu_iiuc@yahoo.com \\ Mustafa Manir Chowdhury \\ Associate Professor \\ Department of Business Administration \\ International Islamic University Chittagong, Bangladesh \\ E-mail: mmanir7@yahoo.com \\ Mrs. Nazneen Jahan Chowdhury \\ Associate Professor \\ Department of Business Administration \\ International Islamic University Chittagong, Bangladesh \\ E-mail: nazneenchy@yahoo.com \\ Mohammad Emdad Hossain \\ Associate Professor \\ Department of Business Administration \\ International Islamic University Chittagong, Bangladesh \\ E-mail: mehapstat@gmail.com \\ Sayed Md. Hashib Ahsan \\ Assistant Professor \\ Department of Business Administration \\ International Islamic University Chittagong, Bangladesh \\ E-mail: hasib27.ahsan@gmail.com
}

\begin{abstract}
Poverty is one of the problems in third-world countries like Bangladesh. There has been an ongoing battle against challenging living conditions-overcrowding, floods, deforestation, erosion, soil depletion, and natural calamities. Quite a lot of programs have been tried since the independence of Bangladesh in 1971, and to tell the truth, most have failed. Each time an antipoverty program fails, it gives more fuel to the richer class to argue that there's no point in trying to help the poor. However, this is an age of information technology. Almost all of the spheres of human life are contributed by Information technology. Information Technology can change the fate of the poor by helping them to be with the current time and happenings by ensuring their
\end{abstract}


capabilities to access information. The Government of Bangladesh also realizes the importance of the issue, and recently they concentrated on transforming the government services to digitize. As one of the initiatives to empower the poor with information, GOB has launched Union Information and Service Centre (UISC) in all of the Union councils of the country. The private sector started digitization of operations earlier than the government. Now, as the government has also initiated the process, the journey will get a smooth and parallel speed to develop the socio-economic condition of the poor of the country. This paper attempts to explore the capabilities of ICT to reduce poverty in Bangladesh. The study will also try to suggest how ICT can be better used to eradicate poverty. ICT is a rapidly growing field in Bangladesh in recent times. The contribution of ICT in every sector of the country is trying to be addressed to improve the situation. This study is conducted by reviewing the studies in this line to suggest better policies to be formulated. The results show that ICT has excellent capabilities to alleviate poverty despite many challenges to be faced.

Keywords: ICT, Poverty, Alleviation, UISC.

\section{INTRODUCTION}

Bangladesh is a developing country with a population of about 180 million (Bangladesh Bureau of Statistics). Natural calamity is a common phenomenon in Bangladesh. Moreover, the level of education of its population is not up to the standard. So the standard of the life of the inhabitants is also not at a high level. Agriculture is the main source of income for most of the country's men. Readymade Garments are the main source of foreign currency, followed by the manpower exporting sector. Yet, poverty is a great problem in this country still now. The people of Bangladesh are to fight against a lot of issues. Notably, $30 \%$ of the country's men live below the poverty line (Bangladesh Bureau of Statistics). Poverty is being reduced at a slow pace. Every government tried to reduce poverty by taking several programs after the independence of the country. Most of the programs taken for poverty alleviation failed due to proper planning and applicability.

Additionally, corruption is another great reason for making the programs unsuccessful. However, this is an age of information and communication technology. ICT applications avail almost all spheres of human life. Developed countries are using ICT in various sectors to get benefits at an advanced level. ICT has multidimensional applications. Information Technology can play roles from the root to the advanced level to develop the economy and a nation. In Bangladesh, there are many scopes for ICT to contribute both at the root level and the advanced level. ICT has vast potential in this fast-developing economy of Bangladesh. There are many sectors to be addressed by ICT in the context of Bangladesh.

\section{Objectives of the Study}

- To find out the current situation of poverty in the country

- To study about the capability of ICT in case of alleviating poverty

- To suggest how ICT can be better used in reducing poverty

\section{LITERATURE REVIEW}

Several studies have been conducted regarding the roles of ICT in poverty alleviation. But it is still at the primary level. Bayes et al. (1999) showed how to promote the poor's economic development through Village Pay Phones (VPPs). Dymond and Oestmann (2002) offer a basic concept and real 
base for discussing the role of ICTs in developing poor communities. Kenny et al. (2000) argue that recent econometric studies have found increasing evidence of a causal link between telecommunications development and economic development. In a study, Heeks (1999) suggests that ICTs play a role mainly in communications technologies rather than information-processing or production technologies. Bello and Aderbigbe (2014) highlighted some of the benefits the developing countries can derive from the use and adoption of ICT and some problems they encounter, and what the government of these developing countries can do to assist in the implementation of ICT. Anita Vitanen (2005) concluded that the role of ICT is catalytic in the complex task of poverty reduction by leveraging the effects on earnings opportunities, on educational and health services, on good governance, and on promoting democracy. Okello et al. (2014) discussed two objectives regarding the roles of ICT in poverty alleviation-the; the first objective was to study the application of ICT in economic growth, and the second was to investigate the role of ICT as a poverty reduction strategy. The paper clarified the debate on the role of ICT, and gave a framework for extending the discussion so that ICT may find its rightful place in development cooperation. Abiodun and Sunday (2013) suggested appropriate policies for the efficient use of ICT in reducing poverty and bridging the gap between the poor and the rich in Nigeria. Chowdhury et al. (2013) conducted a study on the role of ICT as an anti-corruption tool to prevent corruption from complying with Shariah rules.

\section{ICT CAPACITY TO REDUCE POVERTY}

\section{ICT Capacity to Reduce poverty has been discussed below}

\section{Through Creating Opportunities for the Poor}

a) Creating market for their products and providing market information: Bangladesh is an agricultural country. Most of the people of this country are involved in agriculture, varying from production to market. Farmers are the poor not because of their fate only. They are, in one sense, exploited due to the lacking of proper information about the demand of their product, Price, Market trends, information regarding good seeds, etc. Electronic commerce has created the opportunity for everybody to be with current business trends. Farmers or producers are also empowered with relevant information nowadays. They are no more bound to act according to the so-called intermediaries. Even though their products are not of that standard to be transacted online, their bargaining power is increased, which helps them to be saved from exploitation and get the proper prices with more alternatives.

b) Developing the agro-based industry by getting relevant information: Innovation and research are common phenomena in the developed countries. New ideas regarding the development of hybrid crops and other agro-based products like poultry, dairy, fisheries are going home and abroad. In addition to this, there is information related to the modern way of cultivation and maintenance of every sector of agriculture. The village farmers can log into these creative ideas through the internet and have knowledge about this innovation to apply in their own farms.

\section{Through Empowering the Poor}

a) Communication and collaboration: Communication is the most powerful requirement for success in every sector nowadays. ICT has facilitated communication in such a way that the whole 
globe has become a village. People of every level poor to reach have equal opportunities to be with the world with necessary information.

b) Union information service centre: The government of Bangladesh has initiated the Union information service centers, which help the remote people be empowered by basic information.

c) Education opportunity for the offspring of the poor of the village: Education is the precondition for alleviation of poverty and the development of a nation as well. Once, it was a dream and, in some cases, impossible for the poor to get their offspring educated. Now, it is not a problem to get their offspring educated in the country's highest institution as they can access all necessary information regarding their requirements of admission and study.

d) Creating opportunities to find out various financial and other resources as (competitive Ones) to invest in potential fields to gain benefits: Financing any small or medium project is a challenge for the poor as they suffer from the proper source of finance at a lower cost. Most of the poor are bound in the hands of a limited number of NGOs for getting loans at high cost and consequently being exploited. The financial market and institution have expanded in such a volume that it has made the chance for the poor to choose to lend money competitively for investing. Moreover, ICT had empowered the borrower to find the financial market online, get information, and compare borrowing money.

e) Health affairs of women and children: Poor people suffer a lot from the unconsciousness of health affairs. Most of the women and children among poor $\mathrm{p}$ are unhealthy. The sick population cannot contribute to the nation with a total capacity which is one of the causes for their worst condition and of the nation as well. Nevertheless, the internet availability and huge information regarding the development of consciousness among mass people has enabled the poor to maintain a healthy life. It has contributed to building up an energetic nation for building the whole nation.

f) Getting online helps reduce cost and save time: One of the benefits of telecommunication is getting online service in most cases. Online service saves people from physical movement and thus saves money and energy to get the service.

g) Automatic Land registration saves the poor from being deceived and losing their lands: This was a common problem that poor people were deceived by fraudulence in registering their lands. Often their land registration is not done transparently. There were kept some loops and holes to exploit them in the future. In some cases, the poor would have to lose their lands even. It has been checked and stopped by introducing automatic land registration.

h) Forecasting natural calamity helps to take necessary action in advance: Natural calamities are very frequent and common in most of the coastal countries of Asia. Bangladesh is also not an exception. Natural calamities hamper the production of crops, damaged houses, and cause diseases. CT is deployed now to predict calamities, which will help the coastal people get the information of such type of disaster in advance and take precautions to minimize the harm.

i) Ensuring their right by checking corruption: Corruption is one of the roots of poverty in underdeveloped countries. The mass people are bound in a sense in the hand of the public servant 
to get their legitimate rights. Besides, it has become easier to exploit poor people in various public sectors because of the unavailability of automation.

\section{Here are some sectors mentioned where ICT can be used to control corruption in developing countries:}

a) Procurements: All sorts of public procurement must be completed electronically. It will help to minimize the chance of the public servant to transact speed money or bribe. Consequently, it will help to save the money of the poor public. This saved money can contribute to the national economy being healthy and reinvested for growth.

b) Electronic Voting System: Election is a way to change the power of ruling the country. The poor can get the least scope to take part in making changes of government. Sometimes they are deprived of making their choice in a manual voting system as the system is politicized and controlled by the ruling party. The electronic voting system can eradicate this malpractice by ensuring the rights of the poor. Consequently, they can choose a government that will favor their development and takes the program to eradicate poverty in a true sense.

c) Preparing Automatic Billing: All sorts of billing like electricity and others may be prepared by computer so that no man hand can manipulate the reading which minimizes the corruption. Thus the consumer can be saved from paying fraud bills.

d) E-Ticketing system: E-Ticketing system can reduce the chance of selling transportation tickets like Train in the black market. It will help the poor get the ticket at a real price, which will help them frequently search for jobs or other services.

e) Empowerments in manpower exporting: Preparing passport, checking the job status in case of going abroad and thus checking the fraudulence, going abroad under G2G arrangement by themselves without the help of a broker can save the poor from being deceived.

f) Ensuring accountability in public services: CT can also assist people in monitoring and accountability of development programs in their locality.

\section{Through Training and Development}

a) Exporting Manpower: Ready Made Garment sector is the largest of all foreign currency earning sectors of the country. Bangladesh owns a significant number of populations as a resource gifted by the Almighty besides other natural resources. The second one is exporting Human resources abroad. Most of the people exported are unskilled laborers, which does not help to yield good returns. This resource can be trained up in ICT as other trades in the demand of developed countries to have a handsome foreign exchange from this human resource.

b) Outsourcing: Providing third-party service through outsourcing in data entry: Information Technology itself has become a source of earning foreign currency by outsourcing which is considered one of the alternatives of RMG. In RMG, the unskilled labor is deployed with a lower payment, whereas outsourcing needs skilled manpower and gives better returns. The paradigm is being shifted from labor-intensive and lower payment to that of skilled and higher payment. 
c) Innovating new ideas in production and service sectors: The country moves towards automation in all of its sectors. The manpower of the country is brilliant enough to innovate new ideas in developing new IT-based products and improving the quality of services by using IT, which helps them make more profit and reinvest in the farms, which creates more employment for the poor in all sectors.

We can try to figure out some problems regarding the full-fledged implementation of ICT in Bangladesh:

- ICT infrastructure: As Bangladesh is a developing country with a large population, it is quite challenging to establish the infrastructure in information and communication technology at massive scales to facilitate digitization as declared by the government.

- Power: Power is a precondition for ICT to run. If even the infrastructure is ready, the country lacks the generation of power, and thus it is of no use. So the government and the private sector should come forward with the power plant to generate sufficient power to keep the nation online.

- Level of education: The technical skill of the inhabitants of the country is not favorable for taking the benefits of ICT. So although there are opportunities for them to take advantage, they are still being exploited by the clever intermediaries.

- To practice E-commerce in a country, Government offices, including tax, revenue, utilities, etc., have to be computerized and online accessible first. But, most offices are not interested in computerizing their system because the computerized system is an obstacle to corruption or they don't like the machine.

\section{CONCLUSION}

Despite a lot of problems, Bangladesh is making continuous development in every sector. The asset of the country is its hard-working human resource. The major problem is the lack of good governance to utilize the resource gifted by the Almighty. Information and communication system in Bangladesh has been launched but still a long way to get full speed. If the government takes initiatives to make their declaration of digitization a reality, it will help the percentage of poverty decrease by a considerable amount.

\section{REFERENCES}

Abiodun, O. O., \& Sunday, A. I. (2013). Poverty alleviation through information and communications technology: A case study of Nigeria. International journal of multidisciplinary sciences and engineering, 4(7), 20-24.

Bello, O. A., \& Aderbigbe, F. M. (2014). The role of ICT in national development and poverty alleviation. Impact: International journal of research in Engineering \& technology, 2(5), 275-284.

Bayes, A., Von Braun, J., \& Akhter, R. (1999). Village pay phones and poverty reduction: Insights from a Grameen Bank initiative in Bangladesh (No. 8). ZEF Discussion Papers on Development Policy.

Chowdhury, M.S. A., Khan, M. M., \& Akter, S. (2013). Corruption in Islamic Perspective and the Roles of Information and Communication Technology (ICT) to Control It. European Journal of Business and Management, 5(11), 36-43. 
Dymond, A., \& Oestmann, S. (2002). Rural telecommunications development in a liberalising environment: An update on universal access. Vancouver, BC: Intelecon Research \& Consultancy

Heeks, R. (1999). Information and communication technologies, poverty and development. Development informatics working paper, (5).

Kenny, C. J. (2000). Expanding Internet access to the rural poor in Africa. Information Technology for Development, 9(1), 25-31.

Vitanen, A. K. (2005). The Role of ICT in Governing Rural Development, Paper presentation in the IFAD Workshop on the What are the Innovation Challenges for Rural Development, hold in Rome on 15 to $17,11-14$

Okello, G., Ouma, E., Maritim, K., \& Adhiambo, M. (2014). The role of ICT in economic growth and poverty reduction. International Journal of Arts and Commerce, 3(3), 35-48

\section{Copyrights}

Copyright for this article is retained by the author(s), with first publication rights granted to the journal. This is an open-access article distributed under the terms and conditions of the Creative Commons Attribution license (http://creativecommons.org/licenses/by/4.0) 